\title{
HUBUNGAN KEMAMPUAN KOMUNIKASI PENUGASAN KEPALA MADRASAH DENGAN KINERJA GURU MADRASAH ALIYAH DI KOTA TANJUNGBALAI
}

\author{
Dailami \\ Fakultas Keguruan dan Ilmu Pendidikan, Universitas Asahan (FKIP UNA) Kisaran \\ pakdailami@gmail.com
}

\begin{abstract}
ABSTRAK
Penelitian ini bertujuan untuk mengetahui bagaimana hubungan kemampuan komunikasi penugasan Kepala Madrasah dengan kinerja guru Madrasah Aliyah Kota Tanjungbalai. Populasi penelitian ini adalah guru Madrasah Aliyah Tanjungbalai yang berjumlah 162 orang. Teknik sampling yang digunakan adalah Stratified Random Sampling, dengan jumlah sampel yang diperoleh adalah 38 orang. Instrumen yang digunakan untuk mengumpulkan data adalah angket skala likert dan diolah dengan teknik analisa cronbach. Hasil ujicoba dan perhitungan menunjukkan bahwa variabel kemampuan komunikasi penugasan Kepala Madrasah (XI) rtt=0,866 dan variabel kinerja guru Madrasah Aliyah Kota Tanjungbalai $(Y) r t t=0,880$. Teknik analisis yang digunakan adalah teknik analisis korelasi dan regresi. Seluruh pengujian menggunakan taraf kepercayaan 95\% pada $\alpha=0,05$. Hasil analisis menunjukkan bahwa $r_{\mathrm{xt}}=0,967$ dan $R^{2}=0,935$, Hal ini menunjukkan terdapat hubungan yang kuat kemampuan komunikasi penugasan Kepala Madrasah dengan kinerja guru Madrasah Aliyah Kota Tanjungbalai $(Y) 0,935 \times 100 \% \boldsymbol{r}_{\mathrm{y} 1}=93,5 \%$.
\end{abstract}

\section{Kata Kunci : Kemampuan Komunikasi; Kinerja Guru}

\section{PENDAHULUAN}

Guru merupakan salah satu komponen utama dalam mendukung peningkatan mutu sumber daya manusia, sehingga secara terus menerus berupaya meningkatkan kualitas sumber daya manusia melalui penataan sistem pendidikan nasional secara komprehensif. Penataan, pengembangan dan pemantapan sumber daya manusia perlu ditumbuhkan secara efisien agar sasaran pembangunan mutu pendidikan yang berkesinambungan dapat tercapai.

Madrasah Aliyah sebagai salah satu jenis pendidikan agama merupakan lembaga pendidikan menengah dimana eksistensinya tidak dapat diabaikan. Madrasah Aliyah merupakan wadah penyelenggaraan pendidikan dibidang intelektual memikul beban yang berat dalam upaya mewujudkan tujuan pendidikan. Komunikasi penugasan pimpinan yang dalam hal ini Kepala Madrasah juga dianggap mempengaruhi keberhasilan tugas guru. Keberadaan Kepala Madrasah sebagai sutradara sekaligus aktor yang paling berperan dalam proses manajemen harus dapat menciptakan situasi yang kondusif. Kepala Madrasah merupakan sosok pemimpin dan sekaligus bertindak sebagai seorang arsitektur di lembaga pendidikan, artinya sebagai seorang pemimpin, Kepala Madrasah harus dapat membina bawahan dan membawa ke arah yang lebih baik melalui komunikasi penugasan yang efektif sehingga timbul etos kerja dan kepuasan kerja baik secara psikis, fisik maupun lingkungan. Senada dengan hal ini Happoch dalam Hoy da Miskel (1978) menyebutkan bahwa "Job Satisfaction is any combination psychological and evironmental circumstances".

\section{TUJUAN KAJIAN}

a. Untuk mengetahui besarnya hubungan kemampuan komunikasi penugasan Kepala Madrasah dengan kinerja guru Madrasah Aliyah di Kota Tanjungbalai.

b. Untuk mengetahui pengembangan komunikasi Kepala Madrasah di Kota Tanjungbalai 


\section{OBJEKTIF KAJIAN}

a. Apakah terdapat hubungan kemampuan komunikasi penugasan Kepala Madrasah dengan kinerja guru Madrasah Aliyah di Kota Tanjungbalai?

b. Bagaimana pengembangan komunikasi Kepala Madrasah di Kota Tanjungbalai?

\section{TINJAUAN PUSTAKA}

\section{Kemampuan Komunikasi Penugasan Kepala Madrasah}

Manusia sebagai makhluk sosial selalu berhunbungan dengan orang lain, berteman dan berkelompok. Kehidupan dalam kelompok biasanya ditandai dengan adanya kegiatan melalui komunikasi sehingga komunikasi merupakan bagian yang tidak dapat dipisahkan dari kehidupan berkelompok. Lewis (1987) menyatakan bahwa "communication is the exchange of messages resulting in a degree of shared meaning between a sender and receiver". Komunikasi merupakan pertukaran pesan yang menghasilkan pertukaran makna antara pengirim dan penerima pesan. Proses seperti ini berlangsung dalam seluruh dimensi pergaulan hidup manusia. Menurut Gondokusumo (1986) dalam hubungan kerja kita mengenal komunikasi informasi dan komunikasi penugasan. Yang pertama menyampaikan informasi saja, sedangkan yang kedua adalah cara memberikan tugas supaya diselesaikan dengan efisien. Komunikasi yang dimaksud dalam penelitian ini adalah komunikasi dalam memberikan tugas atau dikenal dengan komunikasi penugasan. Dalam komunikasi penugasan segala sesuatu yang menyangkut pelaksanaan tugas hendaknya direncanakan dan disusun dengan sebaik-baiknya agar dapat dikomunikasikan dengan jelas. Penyampaian komunikasi dalam penugasan dapat berbentuk lisan atau tulisan. Proses penyampaian informasi atasan dan bawahan akan terlaksana didalam komunikasi penugasan.

Sehubungan dengan persoalan komunikasi penugasan atasan kepada bawahan, Davis (1962) mengatakan bahwa komunikasi ke bawah berarti informasi yang mengalir dari orang yang wewenangnya lebih tinggi kepada orang yang wewenangnya lebih rendah. Yuwono (1978) memberikan penjelsan bahwa pelaksanaan komunikasi ke bawah dapat berupa : 1) pemberian petunjuk, yaitu petunjuk-petunjuk bagi bawahan dalam melaksanakan tugas-tugasnya, 2) pemberian keterangan umum, yaitu keterangan yang bersifat umum tidak menyangkut bidang tugas tertentu, 3) pemberian perhatian, yaitu informasi yang secara autoritatif menunjukkan kepada bawahannya tentang apa yang harus dikerjakan, 4) pemberian teguran, yaitu pimpinan menunjukkan kesalahan atau kekurangan yang ada pada bawahan dalam melaksanakan tugas-tugasnya, 5) pemberian pujian, yaitu pimpinan memberikan pujian pada bawahan yang telah berhasil melaksanakan pekerjaan dengan baik. Berdasarkan pada pendapat yang telah dikemukakan di atas, maka dapat dikatakan bahwa arus komunikasi dari atas ke bawah merupakan pemberian informasi yang disampaikan oleh atasan melalui komunikasi penugasan. Maksudnya, dengan informasi tersebut antara lain seseorang dapat digerakkan untuk melakukan sesuatu yang diinginkan oleh pemberi informasi. Informasi yang dikomunikasikan itu hendaknya jelas, lengkap dan mudah dimengerti. Dengan informasi yang demikian itu diharapkan dapat mengurangi kegagalan dalam melaksanakan tugas. Oleh karena itu, informasi yang disampaikan haruslah relevan, tepat waktu dan dapat dipercaya. Sejalan dengan pendapat tersebut, Komaruddin (1991) mengemukakan bahwa komunikasi penugasan itu haruslah jelas, relevan dan tepat pada waktunya. Kalau informasi itu tidak disampaikan dengan jelas baik secara lisan maupun tulisan maka akan terjadi kesalahpahaman.

Agar informasi itu efektif dan dapat diterima dengan baik dan benar, maka perlu diperhatikan juga penggunaan bahasa yang tepat dan tidak berbelit-belit. Yuwono (1985) mengemukakan beberapa syarat penggunaan bahasa dalam penyampaian informasi, antara lain : a) kata-kata yang dipergunakan untuk melukiskan suatu hal hendaknya sederhana tetapi jelas, b) menggunakan perkataan yang nyata yang dapat menimbulkan gambaran tertentu. Jika menggunakan perkataan abstrak hendaknya diberikan contoh, c) memilih kata-kata yang tepat dalam melukiskan ide, d) kalimat yang digunakan hendaknya tidak terlalu panjang. Selain itu dalam komunikasi penugasan harus diperhatikan unsur-unsur dari tugas itu, kemampuan dan faktor-faktor lain pada bawahan yang mendorong atau menghambat penyelesaian tugas. Disamping itu, komunikasi harus merangsang dan mendorong bawahan untuk berprestasi. 


\section{Kinerja Guru}

Robbins (1996) menyebutkan bahwa kinerja adalah ukuran dari hasil yang dilakukan dengan menggunakan kriteria yang disetujui bersama. Kriteria yang dipakai sangat tergantung pada faktorfaktor yang terkait dengan pekerjaan, misalnya kriteria kinerja untuk pimpinan perusahaan berbeda dengan pimpinan suatu lembaga pendidikan meskipun keduanya pimpinan suatu organisasi. Di lembaga pendidikan produk bukan dalam bentuk barang melainkan kualitas hasil lulusan yang dapat bersaing antara lain dapat diterima di lapangan kerja dan diakui oleh masyarakat.

Kinerja merupakan kemampuan individu dalam melaksanakan tugas dan tanggung jawab yang sesuai dengan tuntunan pekerjaan tersebut. Dengan demikian keberhasilan seseorang dapat diukur bagaimana kinerja yang ditampilkannya. Kinerja guru akan memberikan kontribusi terhadap prestasi kelompok dimana ia menjadi anggotanya, karena setiap guru biasanya bekerja pada suatu bidang atau bagian, jika guru memberikan prestasi tentu saja prestasi tersebut memperngaruhi kelompok kerja secara keseluruhan. Guru di lembaga pendidikan merupakan sosok yang secara langsung setiap hari bekerja menurut tugas yang telah ditentukan, tugas-tugas tersebut biasanya tertera diatas meja masingmasing sesuai dengan petunjuk dan keputusan yang telah ditetapkan oleh pimpinan organisasi. Dalam bekerja para guru tersebut secara rutin melaksanakan tugas setiap hari sesuai dengan tanggung jawabnya dan mereka pada dasarnya tidak memiliki wewenang untuk mengambil keputusan.

Perilaku yang tepat dan menarik perhatian guru perlu dilakukan, karena perlakuan yang baik akan menghasilkan perasaan yang tenang dikalangan guru tersebut. Pimpinan yang dalam hal ini Kepala Madrasah harus selalu memperhatikan guru maupun pegawai, ada beberapa hal yang harus diperhatikan pimpinan terhadap guru. Untuk mengukur bagaimana sebenarnya kinerja guru maka indikator yang akan dijadikan alat ukurnya adalah: sifat tugas, uraian tugas, etos kerja, program kerja, pelayanan sesuai bidang tugas.

\section{METODE PENELITIAN}

Penelitian ini dilakukan di Madrasah Aliyah Negeri dan Swasta Kota Tanjungbalai dengan subjek penelitian adalah guru. Peneliti lebih memfokuskan pada masalah kinerja guru. Penelitian ini bersifat deskriptif. Populasi penelitian adalah seluruh guru Madrasah Aliyah Negeri dan Swasta Kota Tanjungbalai berjumlah 162 orang sedangkan sampel penelitian dilakukan dengan cara stratified proportional random sampling. Teknik ini menghasilkan sampel yang memperhatikan proporsi setiap kelompok sekaligus memberikan peluang yang sama kepada semua anggota populasi untuk dipilih menjadi sampel. Dari hasil perhitungan maka jumlah sampel yang terpilih adalah 38 orang.

\section{a. Identifikasi Strata}

Strata yang digunakan dalam penentuan sampel adalah tingkat pendidikan terdiri dari sarjana sebanyak 120 orang dan pascasarjana sebanyak 42 orang, masa kerja yang $\leq 4$ tahun sebanyak 50 orang dan $>4$ tahun sebanyak 112 orang, jenis kelamin dimana terdiri dari pria sebanyak 72 orang sedangkan wanita sebanyak 90 orang.

\section{b. Menghitung proporsi strata}

Berdasarkan pada masing-masing strata kelompok populasi maka diperoleh proporsi masing-masing strata sebagai berikut:

1) Untuk strata pendidikan

$$
\begin{array}{ll}
\text { S1 } 1=120 \text { orang, } & \mathrm{P} 1=120: 162=0,74 \\
\text { S2 }=42 \text { orang, } & \mathrm{Q} 1=1-0,74=0,26
\end{array}
$$

2) Untuk strata masa kerja

$$
\begin{array}{ll}
>4 \text { tahun }=112 \text { orang, } & \text { P2 }=112: 162=0,69 \\
\leq 4 \text { tahun }=50 \text { orang, } & \text { Q2 }=1-0,69=0,31
\end{array}
$$

3) Untuk strata jenis kelamin 


$$
\begin{array}{ll}
\text { Pria }=72 \text { orang } & \text { P3 }=72: 162=0,44 \\
\text { Wanita }=90 \text { orang } & \text { Q3 }=1-0,44=0,56
\end{array}
$$

\section{c. Ukuran Sampel}

Ukuran sampel ditentukan dengan menggunakan rumus Cochran (1977) dengan rumus :

$$
N_{0}=\frac{t^{2} x p x q}{d^{2}}
$$

Kemudian $N_{0}$ yang terbesar dikoreksi kedalam rumus:

$$
n=\frac{N_{0}}{1+\frac{N_{0}-1}{N}}
$$

Keterangan:

$N_{0}=$ besar sampel tahap pertama

$\mathrm{N}=$ Jumlah populasi penelitian

$\mathrm{n} \quad=$ besar sampel tahap kedua

$\mathrm{t}=$ keeterwakilan populasi oleh sampel yang ditetapkan pada taraf kepercayaan $95 \%$, maka $\mathrm{z}=1,96$

$\mathrm{d}=$ besarnya kekeliruan pengambilan sampel, ditetapkan sebesar $10 \%$

$\mathrm{p}=$ besar populasi kelompok pertama dalam strata

$\mathrm{q}$ = besarnya proporsi kelompok kedua dalam strata atau (1-p)

dengan perhitungan sampel sebagai berikut :

1) $\frac{1,96 x 0,74 x 0,26}{0,01}=37,71=38$

2) $\frac{1,96 \times 0,69 \times 0,31}{0,01}=41,92=42$

3) $\frac{1,96 \times 0,44 \times 0,56}{0,01}=48,29=49$

dari perhitungan diperoleh $\mathrm{N}_{0}$ terbesar adalah 49 , maka

$$
\begin{aligned}
& n=\frac{N_{0}}{1+\frac{N_{0}-1}{N}} \\
& n=\frac{49}{1+\frac{49-1}{162}}=37,98
\end{aligned}
$$

Dari hasil perhitungan yang telah dilaksanakan maka terlihat bahwa strata yang paling besar jumlahnya adalah strata jenis kelamin yaitu 38 orang. Oleh karena itulah maka angka tersebut diambil untuk jumlah sampel .

\section{d. Menentukan subjek penelitian}

Berdasarkan hasil perhitungan diperoleh sampel sebesar 38 orang. Untuk menentukan subjek penelitian diambil secara acak melalui undian pada masing-masing strata, setelah terlebih dahulu menulis nomor setiap anggota populasi pada secarik kertas kemudian digulung. Hal ini dilakukan agar setiap anggota mempunyai peluang yang sama untuk menjadi sampel penelitian.

\section{e. Instrumen Penelitian}

Instrumen yang digunakan dalam mengumpulkan data berupa kuesioner yang disusun untuk mengukur kemampuan manajerial dan kemampuan kinerja guru. Skala pengukuran menggunakan skala likert 
dengan empat alternatif jawaban : sangat tidak setuju (STS), sangat setuju (SS), setuju (S), tidak setuju (TS).

\section{f. Ujicoba Instrumen}

Sebelum menggunakan instrumen terlebih dahulu dilakukan uji coba untuk mendapatkan instrumen yang valid dan reliabel. Responden yang dijadikan sebagai ujicoba diambil diluar sampel penelitian. Cara yang ditempuh adalah dengan memberikan kuesioner kepada guru yang terpilih sebagai responden ujicoba sebanyak 20 orang dan dilaksanakan 2 minggu sebelum pemberian angket kepada responden. Setelah dilakukan ujicoba instrumen didapat validitas sebagai berikut: 1) jumlah kuesioner variabel kemampuan komunikasi penugasan kepala madrasah (X) berjumlah 30 butir, gugur 5 butir, 2) jumlah kuesioner variabel kinerja guru madrasah aliyah (Y) berjumlah 21 butir, gugur 1 butir. Sedangkan hasil uji realibilitas instrumen didapat bahwa : 1) kemampuan komunikasi penugasan kepala madrasah (X1) adalah 0,886 (handal), 2) kinerja guru (Y) adalah 0,880 (handal)

\section{g. Teknik Pengumpulan Data}

Teknik pengumpulan data dilakukan dengan cara memberikan kuesioner guru di Madrasah Aliyah Negeri maupun Swasta Kota Tanjungbalai dengan cara menemui secara langsung responden penelitian.

\section{h. Analisis Data}

Data penelitian diolah dan dianalisis menggunakan statistik korelasi regresi dengan program SPSS.

\section{HASIL PENELITIAN}

\section{Variabel Kemampuan Komunikasi Penugasan Kepala Madrasah (X)}

Rata-rata Variabel Kemampuan Komunikasi Penugasan Kepala Madrasah (X) adalah 76,53 dengan median (titik tengah) adalah 76,00. Angka median 76,00 menunjukkan bahwa 50\% variabel kemampuan komunikasi penugasan kepala madrasah adalah 76,00 keatas dan 50\% nya 76,00 adalah kebawah. Standar deviasi adalah 8,93 dan varians 79,77. Penggunaan standar deviasi untuk menilai dispersi rata-rata dari sampel. Data minimum adalah 61,00 sedangkan data maximum adalah 99,00, maka rangenya adalah $99,00-61,00=38,00$.

\section{Variabel Kinerja Guru Madrasah Aliyah Kota Tanjungbalai(Y)}

Rata-rata Variabel Kinerja Guru Madrasah Aliyah Kota Tanjungbalai (Y) adalah 56,47 dengan median (titik tengah) adalah 76,00. Angka median 56,00 menunjukkan bahwa 50\% variabel kemampuan komunikasi penugasan kepala madrasah adalah 56,00 keatas dan 50\% nya adalah 56,00 kebawah. Standar deviasi adalah 9,08 dan varians 82,53. Penggunaan standar deviasi untuk menilai dispersi ratarata dari sampel. Data minimum adalah 40,00 sedangkan data maksimum adalah 78,00 , maka rangenya adalah $78,00-40,00=38,00$.

\section{Pengujian Persyaratan Analisis}

Data yang diperoleh dari hasil penelitian dianalisis dengan menggunakan statistik menggunakan korelasi product moment. Analisis tersebut harus memenuhi persyaratan yang dikehendaki yaitu : a) uji normalitas, b) uji linearitas, c) uji homogenitas.

\section{a) Uji Normalitas}

Pengujian normalitas data dengan menggunakan analisis kolmogorov-smirnov dan shapiro wilk tes. Pengujian ini dapat memberikan indikasi lebih lanjut apakah data dapat diolah atau tidak dengan menggunakan analisis regresi dengan taraf signifikansi 5\%. Berdasarkan pengolahan yang dilakukan menunjukkan bahwa uji kolmogorov-smirnov dan shapiro-wilk untuk variabel $\mathrm{x}$ adalah 0,059 sedangkan nilai signifikansinya sebesar 0,200 lebih besar dari nilai signifikansi yang ditetapkan yaitu sebesar 0,05 (5\%). Begitu juga dengan menggunakan shapiro wilk tes, dimana diketahui besar nilai kenormalan untuk variabel x lebih tinggi yakni sebesar 0,978 sedangkan nilai signifikansinya sebesar 
0,721 lebih besar dari nilai signifikansi yang ditetapkan sebesar 0,05 (5\%). Uji kolmogorov-smirnov dan shapiro-wilk untuk variabel $\mathrm{Y}$ adalah 0,101 sedangkan nilai signifikansinya sebesar 0,200 lebih besar dari nilai signifikansi yang ditetapkan yaitu sebesar 0,05 (5\%). Begitu juga dengan menggunakan shapiro wilk tes, dimana diketahui besar nilai kenormalan untuk variabel Y lebih tinggi yakni sebesar 0,970 sedangkan nilai signifikansinya sebesar 0,477 lebih besar dari nilai signifikansi yang ditetapkan sebesar 0,05 (5\%). Berdasarkan pengujian diatas, maka untuk menentukan normal atau tidaknya data (X dan Y) mengacu pada Santoso (2012:74) yang menyebutkan bahwa untuk pengambilan keputusan bagi uji normalitas data dapat dipedomani pada dua hal yakni: 1) apabila nilai signifikan $<$ dari 0,05 maka data tergolong tidak normal, 2) apabila nilai signifikan > dari 0,05 maka data tergolong normal. Berdasarkan pendapat ini maka hasil uji normalitas data dari tiap variabel tergolong data normal (> $0,05)$.

\section{b) Uji Linearitas}

Berdasarkan hasil uji linearitas menggunakan uji Anova, masing-masing variabel yaitu kemampuan komunikasi penugasan kepala madrasah (X) terhadap variabel terikat kinerja guru Madrasah Aliyah Kota Tanjungbalai (Y) adalah linier. Data pengujian menunjukkan bahwa nilai $\mathrm{F}$ untuk Variabel X adalah 521,667 dengan tingkat signifikansi yaitu 0,000 jauh lebih kecil dari 0,05. Berdasarkan data tersebut dapat diasumsikan bahwa variabel kemampuan komunikasi penugasan kepala madrasah (X) cenderung dapat dikatakan linier terhadap variabel Y yaitu kinerja guru Madrasah Aliyah Kota Tanjungbalai. Terpenuhinya persyaratan uji linearitas ini dapat dijadikan sebagai pesyaratan lebih lanjut dalam analisis regresi.

\section{c) Uji Homogenitas Data}

Berdasarkan uji homogenitas data Y menunjukkan bahwa nilai signifikan adalah 0,263. Nilai signifikan ini lebih tinggi dari nilai signifikan yang ditetapkan yaitu 0,05. Untuk mengambil keputusan ini, Santoso (2012:112) menyebutkan bahwa data tergolong homogen apabila $>0,05$. Berdasrkan pengujian dapat diambil keputusan bahwa data $\mathrm{Y}$ tergolong data yang homogen.

\section{Pengujian Hipotesis}

Untuk menguji hipotesis digunakan analisis korelasi product moment person. Hasil analisissnya menunjukkan bahwa koefisien korelasi antara variabel kemampuan komunikasi penugasan kepala madrasah (X) dengan kinerja guru Madrasah Aliyah Kota Tanjungbalai (Y) sebesar 0,967 sedangkan probabilitas observasinya sebesar 0,000 . Karena probabilitas observasi lebih kecil dari probabilitas 0,05 maka dengan demikian $\mathrm{H} 0$ ditolak. Kesimpulan pengujiannya adalah terdapat hubungan yang signifikan kemampuan komunikasi penugasan kepala madrasah (X) dengan kinerja guru Madrasah Aliyah Kota Tanjungbalai (Y). Sementara besarnya kontribusi kemampuan komunikasi penugasan Kepala Madrasah (X) dengan kinerja guru Madrasah Aliyah Kota Tanjungbalai (Y) ditunjukkan oleh koefisien determinasi 0,935 dibulatkan menjadi 93,5\%.

\section{Pembahasan Hasil Penelitian}

Berdasarkan analisis yang dilakukan diatas, diketahui bahwa terdapat korelasi atau hubungan yang signifikan antara kemampuan komunikasi penugasan kepala madrasah (X) dengan kinerja guru Madrasah Aliyah Kota Tanjungbalai (Y), hal ini ditandai dengan tingginya nilai korelasi (ryx=0,967 ; $\left.\mathrm{p}=0,00 ; \mathrm{r}^{2}=0,935\right)$. Tingginya korelasi antara kemampuan komunikasi penugasan dengan kinerja guru Madrasah Aliyah Kota Tanjungbalai dipengaruhi oleh lancar dan tingginya frekuensi komunikasi kepala madrasah dengan guru. Lancarnya komunikasi dalam penyelesaian dalam penyelesaian tugas guru pada gilirannya memacu guru untuk menyelesaikan pekerjaan secara tepat dan efektif. Faktor lain yang dianggap turut mempengaruhi pengembangan komunikasi kepala madrasah adalah tingginya frekuensi saling tukar informasi antara kepala madrasah dengan guru dengan melakukan pertemuan diantaranya supervisi yang dilakukan setiap sebulan sekali rapat kerja misalnya menjelang persiapan menghadapi ujian semester, pembagian raport dan persiapan siswa baru. 


\section{PENUTUP}

\section{Kesimpulan}

1. Hasil analisis menunjukkan bahwa koefisien korelasi antara variabel kemampuan komunikasi penugasan kepala madrasah (X) dengan kinerja guru Madrasah Aliyah Kota Tanjungbalai (Y) sebesar 0,967 sedangkan probabilitas observasinya sebesar 0,000. Karena probabilitas observasi lebih kecil dari probabilitas 0,05 maka dengan demikian $\mathrm{H} 0$ ditolak.

2. Hasil analisis menunjukkan terdapat hubungan yang signifikan kemampuan komunikasi penugasan kepala madrasah (X) dengan kinerja guru Madrasah Aliyah Kota Tanjungbalai (Y).

3. Pengembangan komunikasi Kepala Madrasah dengan guru-guru di Kota Tanjungbalai berjalan dengan baik. Hal ini dibuktikan dengan apresiasi guru-guru untuk mengikuti pertemuan di antaranya rapat kerja misalnya menjelang persiapan menghadapi ujian semester, pembagian raport dan persiapan siswa baru.

\section{Saran}

1. Meskipun kinerja guru Madrasah Aliyah di Kota Tanjungbalai sudah berlangsung dengan baik namun menurut peneliti perlu terus ditingkatkan. Hal ini mengingat Kepala Madrasah merupakan pimpinan di madrasah yang memiliki peran dan fungsi strategis guna meningkatkan efisiensi dan efektivitas kerja di madrasah.

2. Pemerintah daerah Kota Tanjungbalai, agar dapat memberikan perhatian dan sekaligus pembinaan yang penuh dalam rangka peningkatan efisiensi dan efektivitas pelaksanaan pendidikan dan pengajaran di Kota Tanjungbalai.

3. Peneliti lain, dari hasil penelitian ini terlihat bahwa masih banyak faktor lain yang mempengaruhi kinerja guru. Memperhatikan hal ini masih terbuka kemungkinan untuk menggunakan variabel dalam penelitian ini untuk diteliti pada masa yang akan datang.

\section{RUJUKAN}

Cochran, William G. 1974. Sampling Techniques. New Delhi Eastern Private Ltd.

Deal, T.E. \& Kennedy, A.A. 1982. Corporate Cultures. Reading, MA: Addison Wesley.

Griffin, Ricky W. 1987. Management, Boston : Houghton Mifflin Company.

Gondokusumo, A.A. 1986. Komunikasi Penugasan. Jakarta:Gunung Agung.

Komaruddin. 1991. Manajemen Kantor:Teori dan Praktek. Bandung:Sinar Baru.

Lewis, Philip. V. 1987. Organizational Communication. New York : John Welly \& Sons, lnc.

Ndraha, T. 2014. Budaya Organisasi. Jakarta:Rineka Cipta.

Robbins, Stephen P. 1996. Essensials of Organizational Behavior. New Jersey : Prentice-Hall. 